\title{
PENGARUH CLASSMARKER TERHADAP HASIL BELAJAR IPS SISWA SEKOLAH DASAR NEGERI 1 BOYOLALI
}

\author{
P. Narjosoeripto1, T. Harsan' ${ }^{2}$, and P.M. Purbosari ${ }^{3}$ \\ ${ }^{1}$ Universitas Veteran Bangun Nusantara \\ 2Universitas Veteran Bangun Nusantara \\ ${ }^{3}$ Universitas Veteran Bangun Nusantara \\ E-mail; moetis meida@yahoo.co.id
}

\begin{abstract}
Abstrak: The purpose of this study was to determine the effect of classmarker applications on social studies learning outcomes at Boyolali 1 Primary School. The method used in this research is research and development. The study population are 21 students in Boyolali 1 Primary School. In this study the authors conducted a product trial at Boyolali 1 Primary School. The subjects in this study were all fifth grade students, amounting to 21 students. The technique of determining the sample using purposive sampling or the selection of research subjects based on the direct choice of the teacher concerned for certain reasons. Data collection techniques using measurement techniques and documentation techniques, with data collection tools in the form of a questionnaire. The data analysis technique used statistical analysis with SPSS version 20. The results showed that the tcount was 2.963 with the table was 1.670 so that it could be written $t$ count $>t$ table $(2.963>1.670)$ which could be interpreted as $H_{1}$ accepted and $H_{0}$ rejected. Based on calculations, it can be concluded that a significant effect on the application of classmarker-based learning evaluation on social studies learning outcomes in fifth grade students at Boyolali State Elementary School.

Keywords; classmarker, learning outcomes, Social Studies.
\end{abstract}

\section{PENDAHULUAN}

Penguasaan ilmu pengetahuan dan teknologi diupayakan untuk mencapai tujuan pendidikan. Tujuan tersebut akan terwujud melalui kurikulum yang akan dirancang. Perkembangan teknologi yang terjadi dewasa ini turut mempengaruhi kurikulum, pembelajaran hingga evaluasi pembelajaran. Pergeseran paradigma sistem pembelajaran mulai nampak pada proses transfer ilmu pengetahuan. Proses pembelajaran yang ada sekarang ini cenderung lebih menekankan pada proses mengajar (teaching), berbasis pada isi (content base), bersifat abstrak serta hanya untuk golongan tertentu (pada proses ini pengajaran cenderung pasif). Seiring dalam perkembangan ilmu dan teknologi ICT, proses dalam pembelajaran mulai bergeser pada proses belajar (learning) dan evaluasi pembelajaran dengan online.

Peran guru pada era teknologi saat ini tidak lagi sebagai sumber utama pembelajaran karena informasi berkembang dengan begitu cepat dan peserta didik mampu mengaksesnya dengan begitu mudah, bahkan bisa jadi lebih cepat dari gurunya. Guru yang hanya mampu memberikan informasi tentang materi pelajaran kepada peserta didik lambat laun akan tergantikan oleh teknologi. Peran guru dalam mengikuti perkembangan teknologi dapat terwujud melalui evaluasi pembelajaran. Karena sebuah proses pembelajaran bahwa komponen yang turut menentukan keberhasilan sebuah proses pembelajaran adalah evaluasi. Melalui evaluasi, guru dapat 
mengetahui perkembangan hasil belajar, intelegensi, bakat khusus, minat, hubungan sosial, sikap dan kepribadian peserta didik serta keberhasilan sebuah program. Micheal Scriven (1969) menyatakan bahwa "evaluation is an observed value compared to some standard," dengan kata lain menyoroti bahwa evaluasi sebagai sarana untuk mendapatkan informasi yang diperoleh dari proses pengumpulan dan pengolahan data (Siti Husnul Bariah, 2017).

Dasar dari evaluasi yang dilakukan guru yang merujuk dari salah satu dasar standar penilaian olehPermendikbud No. 66 Tahun 2013 tentang Standar Penilaian Pendidikan yang isinya bahwa penilaian pencapaian kompetensi pada jenjang pendidikan dasar dan menengah dilaksanakan oleh pendidik, satuan pendidikan, pemerintah dan/atau lembaga mandiri. Hal ini mengartikan bahwa penilaian pencapaian kompetensi oleh pendidik dilakukan dengan tujuan untuk memantau proses, kemajuan, dan perkembangan pencapaian kompetensi peserta didik sesuai dengan potensi yang dimilikinya dan kemampuan yang diharapkan secara kontinyu atau berkesinambungan. Penilaian ini juga untuk memberikan umpan balik atau feed back kepada pendidik agar dapat memperbaiki perencanaan dan proses pembelajaran yang dilakukan oleh guru.

Pentingnya proses penilaian tersebut, juga dijelaskan oleh Chittenden (1994) bahwa tujuan penilaian (assessment purpose) adalah untuk (1). keeping track, (2). checkingup, (3). finding-out, and (4). summing-up. Keempat tujuan tersebut oleh Arifin (2013:15) diuraikan sebagai bertikut: 1. Keeping track, yaitu untuk menelusuri dan melacak proses belajar peserta didik sesuai dengan rencana pelaksanaan pembelajaran yang telah ditetapkan. Untuk itu, guru harus mengumpulkan data dan informasi dalam kurun waktu tertentu melalui berbagai jenis dan teknik penilaian untuk memperoleh gambaran tentang pencapaian kemajuan belajar peserta didik. 2. Checking-up, yaitu untuk mengecek ketercapaian kemampuan peserta didik dalam proses pembelajaran dan kekurangan-kekurangan peserta didik selama mengikuti proses pembelajaran. Dengan kata lain, guru perlu melakukan penilaian untuk mengetahui bagian mana dari materi yang sudah dikuasai peserta didik dan bagian mana dari materi yang belum dikuasai. 3. Finding-out, yaitu untuk mencari, menemukan dan mendeteksi kekurangan kesalahan atau kelemahan peserta didik dalam proses pembelajaran, sehingga guru dapat dengan cepat mencari alternatif solusinya. 4. Summingup, yaitu untuk menyimpulkan tingkat penguasaan peserta didik terhadap kompetensi yang telah ditetapkan. Hasil penyimpulan ini dapat digunakan guru untuk menyusun laporan kemajuan belajar ke berbagai pihak yang berkepentingan.

Tujuan penilaian mendeteksi kemampuan siswa sebagai feedback guru dalam mengajar di kelas. Jenis penilaian sebagai feedback tersebut dalam pendapat Sudijono (2008) mengungkapkan 
bahwa objek dari penilaian terdiri dari tiga aspek, yaitu aspek kognitif, aspek afektif, dan aspek psikomotor. Aspek taksonomi (pengelompokkan) tujuan pendidikan tersebut harus senantiasa mengacu kepada tiga jenis domain (daerah binaan atau ranah) yang melekat pada diri siswa, yaitu (a) ranah proses berfikir (cognitive domain), (b) ranah nilai atau sikap (affective domain), dan (c) ranah keterampilan (psychomotor domain). Sehingga penilaian pada siswa melihat dari aspek menyeluruh proses pembelajaran. Akan tetapi salahsatu penilaian yang berdampak pada output atau lulusan di rapot yaitu berupa nilai pengetahuan. Nilai pengetahuan tersebut masuk dalam kategori aspek kognitif.

Penilaian kognitif dapat dilakukan melalui tes tertulis oleh guru setelah melaksanakan pembelajaran di kelas. Salahsatu tes dalam bentuk pemberian kuis online pada siswa. Hal ini menjadikan inovasi guru dalam melakukan evaluasi pembelajaran yang berbeda dari biasanya. Evaluasi pembelajaran yang dapat diberikan yaitu menggunakan aplikasi classmarker.

Aplikasi classmarker adalah aplikasi untuk membuat quiz online yang dapat digunakan secara gratis. Aplikasi ini hanya dapat diakses secara online. Adapun alamat akses classmarkeradalah pada laman http://www.classmarker.com/. Classmarkertidak hanya digunakan sebagai quiz online dalam bidang pendidikan saja, namun juga dapat digunakan untuk kegiatan bisnis. Tipe tes yang disediakan oleh Classmarkerterdiri atas: multiple choice, true false, free text, grammar, dan essay. Adapun untuk dapat membuat tes pada aplikasi ini, Anda harus melakukan login terlebih dahulu menggunakan akun yang sudah terdaftar. Akan tetapi, jika Anda belum memiliki akun, maka Anda dapat register terlebih dahulu secara gratis.

Beberapa kelebihan yang dimiliki oleh aplikasi classmarker, yaitu sebagai berikut:Aman untuk digunakan; Mudah untuk mendefinisikan pengaturan tes;Tidak mempersyaratkan instalasi software; Mempunyai sertifikat tes dan dapat mendesain sertifikat penghargaan hasil tes; Tes dapat dilakukan untuk publik maupun pribadi;Nilai hasil tes secara otomatis langsung tersedia;Dapat diakses melalui Personal Computer (PC), iPhone, Chromebook, Smart Devices; dan Hasil tes quiz online dapat didownload dan diexport dalam bentuk excel.

Mengacu pada permasalahan di atas, dalam penelitian ini akan diproduksi sistem evaluasi dan penugasan online yang mampu meningkatkan efektifitas dalam proses pembelajaran sehingga menghasilkan nilai siswa. Penelitian ini bertujuan untuk melihat pengaruh penerapan evaluasi pembelajaran berbasis classmarker terhadap hasil belajar IPS pada siswa kelas V di Sekolah Dasar Negeri 1 Boyolali. 


\section{METODE PENELITIAN}

Berdasarkan masalah yang menjadi fokus dalam penelitian ini, yang menekankan pada uji produk dari classmarker berupa melihat pengaruh penerapan evaluasi pembelajaran berbasis classmarker terhadap hasil belajar IPS pada siswa kelas V di Sekolah Dasar Negeri 1 Boyolali. Alasan pengambilan sampel di Sekolah Dasar tersebut adalah karena hasil belajar IPS di kelas V SD N 1 Boyolali masih rendah dan banyak yang belum tuntas Kriteria Ketuntasan Minimal (KKM). Selain itu, di SD N 1 Boyolali belum pernah mengaplikasikan kuis online dalam pembelajaran IPS.

Maka metode yang tepat untuk digunakan adalah metode penelitian dan pengembangan (research and development/ R\&D). Tatik Sutarti (2017) menjelaskan penelitian R\&D adalah penelitian yang digunakan untuk mengembangkan dan memvalidasi produk pendidikan, bukan untuk menguji teori. Model pengembangan Research and Development (R\&D) Bog and Gall yang telah dimodifikasi Sugiyono yang terdiri dari langkah-langkah berikut: (1) potensi dan masalah, (2) pengumpulan data, (3) desain produk, (4) validasi desain, (5) revisi desain, (6) uji coba produk, (7) revisi produk, (8) uji coba pemakaian, (9) revisi produk, dan (10) produksi massal (Sugiyono dalam Suaidah, 2011). Untuk menyingkat waktu penelitian, maka peneliti menyederhanakan model Research and Development Sugiyono menjadi beberapa langkah sebagai berikut: (1) analisis potensi dan masalah, (2) mendesain produk, (3) mengumpulkan materi, (4) membuat produk awal, (5) melakukan uji ahli, (6) merevisi produk, dan (7) melakukan uji lapangan.

Penulis melakukan uji coba produk di Sekolah Dasar Negeri 1 Boyolali. Subjek dalam penelitian ini adalah seluruh siswa kelas V yang berjumlah 21 siswa. Teknik penentuan sampel menggunakan purposive sampling atau pemilihan subjek penelitian berdasarkan pilihan langsung dari guru yang bersangkutan dikarenakan alasan tertentu. Teknik pengumpulan data menggunakan teknik pengukuran dan teknik dokumentasi, dengan alat pengumpul data berupa angket.Teknik analisis data dalam penelitian ini menggunakan metode statistik. Sugiyono (2014: 333) mengemukakan bahwa dalam penelitian kuantitatif, teknik analisis data yang digunakan sudah jelas, yaitu diarahkan untuk menjawab rumusan masalah atau mengkaji hipotesis yang telah dirumuskan. Analisis data penelitian ini menggunakan metode statistik dengan SPSS versi 20.

\section{HASIL DAN PEMBAHASAN}

Penelitian ini dilakukan untuk mengetahui apakah ada pengaruh penerapan evaluasi pembelajaran berbasis classmarker terhadap hasil belajar IPS pada siswa kelas V di Sekolah Dasar Negeri 1 Boyolali. Sampel pada penelitian ini adalah kelas VI A sebagai kelas kontrol dan kelas VB sebagai kelas eksperimen. Sebelum penelitian dilakukan, peneliti mengambil data awal, yaitu nilai 
raport UTS terakhir mata pelajaran IPS kelas V dari guru mata pelajaran. Berdasarkan hasil analisis awal, diperoleh data yang menunjukkan bahwa dua kelas yang dijadikan sebagai sampel dalam penelitian mempunyai varians yang homogen. Artinya kedua kelas tersebut dalam kondisi yang sama sehingga dapat dijadikan sebagai sampel penelitian.

Berdasarkan penyajian dan analisis data penelitian, Uji normalitas digunakan untuk menguji apakah dalam sebuah model $t$-test, mempunyai distribusi normal atau tidak. Suatu distribusi dikatakan normaljika taraf signifikannya $>0,05$, sedangkan jika taraf signifikannya $<0,05$ maka distribusinya dikatakan tidak normal. Pada penelitian ini uji normalitas dianalisis menggunakan SPSS 20.0.

Tabel 1.1 Hasil Perhitungan Uji Normalitas

One-Sample Kolmogorov-Smirnov Test

\begin{tabular}{|c|c|c|c|}
\hline & nilai \\
\hline \multicolumn{3}{|l|}{ N } & 51 \\
\hline \multirow[t]{2}{*}{ Normal Parameters ${ }^{2}$} & \multicolumn{2}{|l|}{ Mean } & 68.47 \\
\hline & \multicolumn{2}{|l|}{ Std. Deviation } & 7.490 \\
\hline \multirow[t]{3}{*}{ Most Extreme Differences } & \multicolumn{2}{|l|}{ Absolute } & .145 \\
\hline & \multicolumn{2}{|l|}{ Positive } & .145 \\
\hline & \multicolumn{2}{|l|}{ Negative } & -.086 \\
\hline \multirow{2}{*}{\multicolumn{3}{|c|}{$\begin{array}{l}\text { Kolmogorov-Smirnov Z } \\
\text { Asymp. Sig. (2-tailed) }\end{array}$}} & 1.033 \\
\hline & & & .237 \\
\hline \multirow[t]{3}{*}{ Monte Carlo Sig. (2-tailed) } & \multicolumn{2}{|l|}{ Sig. } & $.221^{c}$ \\
\hline & $95 \%$ Confidence Interval & Lower Bound & .213 \\
\hline & & Upper Bound & .229 \\
\hline
\end{tabular}

Berdasarkan yang diperoleh dari perhitungan hasil uji kolmogorof-smirnov dapat disimpulkan bahwa data rata-rataberdistribusi normal karena memiliki Asymp.Sign 0,237 > 0,05. Sehingga dapat disimpulkan bahwa data tersebut berdistribusi normal.

Uji homogenitas digunakan untuk menguji apakah dalam sebuah $t$-test data homogen atau tidak. Apabila homogenitas terpenuhi maka peneliti dapat melakukan pada tahap analisa dan lanjutan. Interprestasi uji homogen dapat dilihat melalui nilai signifikan. Jika nilai signifikan > 0,05 maka data dapat dikatakan homogen. Hasil perhitungan uji homogenitas dapat dilihat pada tabel berikut:

\section{Tabel 1.2 Hasil Perhitungan Uji Homogenitas Test of Homogeneity of Variances}

\begin{tabular}{|c|r|r|c|}
\hline $\begin{array}{c}\text { nilai } \\
\text { Levene } \\
\text { Statistic }\end{array}$ & $\mathrm{df1}$ & \multicolumn{1}{c|}{$\mathrm{df} /$} & \multicolumn{1}{c|}{ Siq. } \\
\hline 1.489 & 1 & 48 & .228 \\
\hline
\end{tabular}


Hasil perhitungan tersebut dapat diketahui bahwa nilai signifikannya adalah 0,228 karena nilai signifikannya dari uji homogenitas 0,228 > 0,05 maka data tersebut dikatakan homogen.

Setelah digunakan uji prasyarat dengan uji normalitas dan homogenitas maka dapat digunakan uji hipotesis. Uji hipotesis yang digunakan dalam penelitian ini adalah uji statistik parametrik yaitu Independent Sample T-test. Uji ini digunakan untuk mengambilkeputusan apakah hipotesis diterima atau ditolak.

Tabel 1.3 Hasil Perhitungan uji T-test

Group Statistics

\begin{tabular}{|ll|r|r|r|r|}
\hline & & & & \multicolumn{2}{c|}{$\begin{array}{c}\text { Std. Error } \\
\text { Mean }\end{array}$} \\
\hline nilai & kelas & \multicolumn{1}{|c|}{$N$} & Mean & Std. Deviation & \multicolumn{1}{c|}{ eksperimen } \\
& 26 & 26.58 & 2.283 & .448 \\
& kontrol & 25 & 23.36 & 5.024 & 1.005 \\
\hline
\end{tabular}

Independent Samples Test

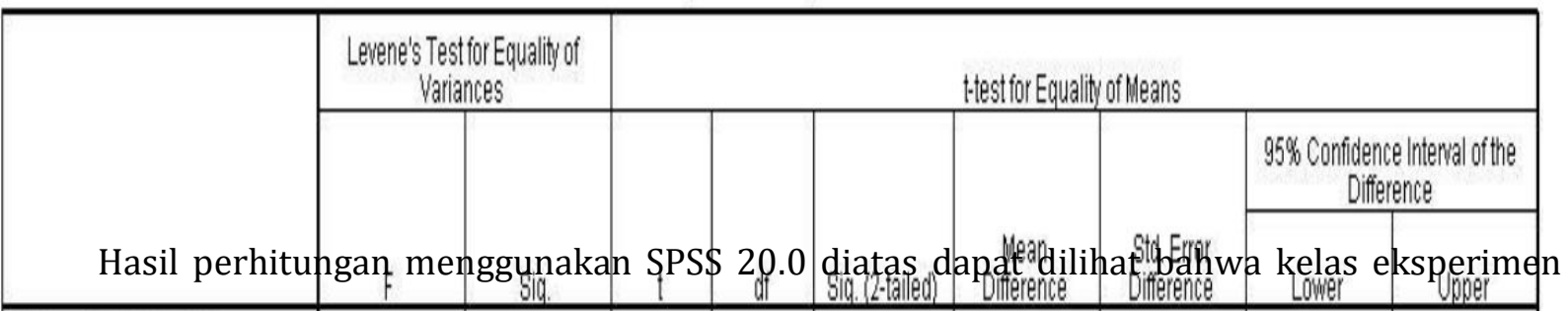

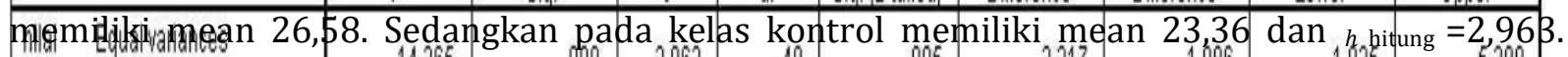
Berdâsarkan hasil tersebut dapat dituliskan $\mathrm{h}$ tabel=1,67. Hal Ini berarti ${ }_{h \text { hitung }}>\mathrm{h}$ table maka Ho Equal variances not

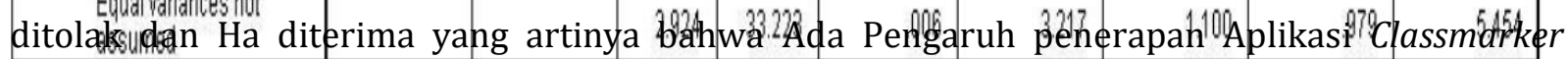
Terhadap Hasil Belajar Ilmu Pengetahuan Sosial pada Siswa Kelas V Sekolah Dasar Negeri 1 Boyolali.

\section{KESIMPULAN}

Berdasarkan hasil penelitian diketahui bahwa penggunaan aplikasi classmarker sebagai alat evaluasi pada pembelajaran IPS pada siswa kelas V SD N 1 Boyolali lebih efektif dan efisien dibanding dengan evaluasi pembelajran konvensional seperti Lembar Jawab Soal di kertas. Bagi guru pembuatan evaluasi pembelajaran dengan classmarker cukup mudah dan lebih efisien, baik dari segi biaya, waktu, maupun tenaga. Hasil penelitian menunjukan bahwadidapatkan $t_{\text {hitung }}$ adalah 2,963dengan $t_{\text {tabel }}$ adalah 1,670 sehingga dapat ditulis $t_{\text {hitung }}>t_{\text {tabel }}(2,963>1,670)$ yang dapat diartikan $\mathrm{H}_{1}$ diterima dan $\mathrm{H}_{0}$ ditolak. Berdasarkan perhitungan, dapat disimpulkan pengaruh yang 
signifikan pada penerapan evaluasi pembelajaran berbasis classmarker terhadap hasil belajar IPS pada siswa kelas V di Sekolah Dasar Negeri 1 Boyolali.

\section{ACKNOWLEDGEMENT}

Ucapan terima kasih penulis sampaikan kepada Kemenristek Dikti DRPM yang telah membiayai penelitian ini. Serta juga ucapan terimakasih pada semua pihak lain yang tidak bisa penulis sebutkan satu persatu yang telah membantu dalam penyelesaian penelitian ini.

\section{BIBLIOGRAFI}

BSNP. 2006. Model KTSP dan Model Silabus Mata Pelajaran SD/MI. Jakarta: BP.

Divayana, D.G.H. 2018. "Pengembangan model Evaluasi Berbasis Nilai-Nilai Aneka Untuk Meningkatkan Kualitas Pembelajaran Komputer". JurnalKependidikan, Volume 2, Nomor 1, Mei 2018, Halaman 128-140.

http://www.classmarker.com (diakses pada tanggal 2 Oktober 2018 pukul $15.00 \mathrm{WIB}$ ).

Hadley, G.R.L dan Young, D.C. 2018. "Glimpse Inside: Considering the Impact of Curriculum Outcomes and Personal Ideology on Social Studies Pedagogy: A Study Summary St. Francis Xavier". Journal of InternationalSocial Studies, v. 8, n. 1, 2018, pp. 37-61.

Jang, E. E., \& Wagner, M. 2013. Diagnostic feedback in language classroom. In A. Kunnan (Ed.), Journal of Companion to language assessment.

Kece, M. 2014. "Problems Related to the Teaching of Social Studies andSuggestions for Solution: Teachers' Opinions Based on a Qualitative

Research". Journal of Procedia - Social and Behavioral Sciences, March 2014.

M. Anwar Nurkholis1,dan Badawi 2019. Profesionalisme guru di era revolusi Industry 4.0, Proseding Seminar Nasional Program Pendidikan Pascasarjana Universitas PGRI Palembang, Januari 2019.

Narjosoeripto, Harsan, T dan Purbosari, P.M. 2018. Trial Classmarker Test On The Results Of Social Knowledge Science In Basic School Student. Internasional Conference On Applied Science and Engineering 2018.

Setemen, K. 2010. "Pengembangan evaluasi pembelajaran online"e. JurnalPendidikan dan Pengajaran, Jilid 43, Nomor 3, Oktober 2010, hlm.207-214.

Sugiyono. 2007. Metode Penelitian Kuantitatif Kualitatif dan R\&D. Bandung: Alfabeta.

Sukardi. 2008. Metode Penelitian Kualitatif, Kuantitatif dan R \& D. Bandung: Alfabeta.

Sukmadinata. 2009. Metode Penelitian Pendidikan. Bandung: Remaja Rosdakarya.

Suyoso dan Nurohman, S. 2015. "Pengembangan Modul Elektronik Berbasis Web sebagai Media Pembelajaran Fisika”. Jurnal Pendidikan IPA UADYogyakarta Mei 2015. 